\title{
CATATAN REDAKSI
}

Assalamu'alaikum Wr.Wb.

Segala puji bagi Allah Tuhan Pemilik Semua Ilmu. Salam hangat dari Redaksi yang kali ini menghadirkan Pharmacon Volume 12 No 1. Edisi kali ini diawali dengan artikel tentang uji in vivo jamur Lingzhi pada tikus dislipidemia. Uji in vivo lain ditampilkan pada aktivitas kemopreventif dari kulit jeruk keprok.

Docking, sebagai sebuah penelitian in silico ditampilkan dengan mengangkat topik tentang analog kurkumin. Selanjutnya dihadirkan pula dua buah penelitian mengenai aktivitas antioksidan. Artikel tentang formulasi suspense siprofloksasin dan aktivitas antibakteri serta uji BST kulit dan biji kelengkeng melengkapi edisi kali ini.

Semoga Pharmacon makin bermanfaat bagi pembaca. Kami selalu menantikan kritik dan saran. Selamat membaca

Wassalamu'alaikum Wr. Wb

Redaksi 